\title{
Large mixing ratios of atmospheric nitrous acid (HONO) at Concordia (East Antarctic Plateau) in summer: a strong source from surface snow?
}

\author{
M. Legrand ${ }^{1,2}$, S. Preunkert ${ }^{1,2}$, M. Frey ${ }^{3}$, Th. Bartels-Rausch ${ }^{4}$, A. Kukui ${ }^{5,6}$, M. D. King ${ }^{7}$, J. Savarino ${ }^{1,2}$, \\ M. Kerbrat ${ }^{1,2}$, and B. Jourdain ${ }^{1,2}$ \\ ${ }^{1}$ CNRS, Laboratoire de Glaciologie et Géophysique d'Environnement (LGGE), 38041 Grenoble, France \\ ${ }^{2}$ Univ. Grenoble Alpes, LGGE, 38041 Grenoble, France \\ ${ }^{3}$ British Antarctic Survey (BAS), Natural Environment Research Council, Cambridge, UK \\ ${ }^{4}$ Laboratory of Radio and Environmental Chemistry, Paul Scherrer Institute (PSI), 5232 Villigen, Switzerland \\ ${ }^{5}$ Laboratoire des Atmosphères, Milieux, Observations Spatiales (LATMOS), Paris, France \\ ${ }^{6}$ Laboratoire de Physique et Chimie de l'Environnement et de l'Espace (LPC2E) UMR-CNRS, Orléans, France \\ ${ }^{7}$ Department of Earth Sciences, Royal Holloway University of London, Egham, Surrey, TW20 0EX, UK
}

Correspondence to: M. Legrand (legrand@lgge.obs.ujf-grenoble.fr)

Received: 1 April 2014 - Published in Atmos. Chem. Phys. Discuss.: 12 May 2014

Revised: 13 August 2014 - Accepted: 22 August 2014 - Published: 19 September 2014

\begin{abstract}
During the austral summer 2011/2012 atmospheric nitrous acid (HONO) was investigated for the second time at the Concordia site $\left(75^{\circ} 06^{\prime} \mathrm{S}, 123^{\circ} 33^{\prime} \mathrm{E}\right)$, located on the East Antarctic Plateau, by deploying a long-path absorption photometer (LOPAP). Hourly mixing ratios of HONO measured in December 2011/January 2012 (35 \pm 5.0 pptv) were similar to those measured in December 2010/January $2011(30.4 \pm 3.5 \mathrm{pptv})$. The large value of the HONO mixing ratio at the remote Concordia site suggests a local source of HONO in addition to weak production from oxidation of $\mathrm{NO}$ by the $\mathrm{OH}$ radical. Laboratory experiments demonstrate that surface snow removed from Concordia can produce gasphase $\mathrm{HONO}$ at mixing ratios half that of the $\mathrm{NO}_{\mathrm{x}}$ mixing ratio produced in the same experiment at typical temperatures encountered at Concordia in summer. Using these lab data and the emission flux of $\mathrm{NO}_{\mathrm{x}}$ from snow estimated from the vertical gradient of atmospheric concentrations measured during the campaign, a mean diurnal HONO snow emission ranging between 0.5 and $0.8 \times 10^{9}$ molecules $\mathrm{cm}^{-2} \mathrm{~s}^{-1}$ is calculated. Model calculations indicate that, in addition to around $1.2 \mathrm{pptv}$ of HONO produced by the NO oxidation, these HONO snow emissions can only explain 6.5 to 10.5 pptv of HONO in the atmosphere at Concordia. To explain the difference between observed and simulated HONO
\end{abstract}

mixing ratios, tests were done both in the field and at lab to explore the possibility that the presence of $\mathrm{HNO}_{4}$ had biased the measurements of HONO.

\section{Introduction}

The existence of an oxidizing boundary layer over the Antarctic continent was first highlighted by measurements carried out at the South Pole, where a mean concentration of $2.5 \times 10^{6} \mathrm{OH}$ radicals $\mathrm{cm}^{-3}$ was observed (Mauldin III et al., 2001a), making the South Pole atmospheric boundary layer as oxidative as the remote tropical marine boundary layer (Mauldin III et al., 2001b). Chen et al. (2001) and Davis et al. (2001) showed that the presence of high concentrations of $\mathrm{NO}_{\mathrm{x}}$ produced by the photolysis of nitrate present in surface snow permits the required efficient recycling of $\mathrm{HO}_{2}$ into $\mathrm{OH}$. Aside from snow photochemical emission of $\mathrm{NO}_{\mathrm{x}}$ that acts as a secondary source of $\mathrm{OH}$, the role of atmospheric nitrous acid (HONO) as a primary source of $\mathrm{OH}$ remains unclear. Using a mist chamber followed by ion chromatography analysis of nitrite, Dibb et al. (2004) reported a median HONO mixing ratio close to $30 \mathrm{pptv}$ at the South Pole. However, follow-up measurements by laser-induced fluorescence 
(LIF) indicated lower mixing ratios (6 pptv on average), and an interference with $\mathrm{HNO}_{4}$ has been suspected (Liao et al., 2006). Furthermore, as discussed by Chen et al. (2004) the consideration of $30 \mathrm{pptv}$ of HONO in the lower atmosphere over the South Pole leads to an $\mathrm{OH}$ over-prediction by gasphase photochemical models by a factor of 3 to 5 . The authors questioned whether the discrepancy between observed and simulated concentrations of $\mathrm{OH}$ at the South Pole was due to measurements of HONO suffering from overestimation due to chemical interferences or if the mechanisms of the model missed $\mathrm{HO}_{x}$ and $\mathrm{NO}_{\mathrm{x}}$ losses.

Even at the level of a few parts per trillion by volume (pptv), the presence of HONO requires a source other than the gas-phase reaction of $\mathrm{NO}$ with $\mathrm{OH}$, and many studies measuring $\mathrm{HONO}$ in atmospheres overlying snow-covered regions have suspected HONO to be emitted from the surface snow in addition to $\mathrm{NO}_{\mathrm{x}}$ (see Grannas et al., 2007 for a review). It has to be emphasized that most of the studies of HONO have concerned high (Arctic, Greenland) and middle (Colorado and Alps) northern latitudes where, in relation to the chemical composition of snow, the involved HONO production processes would be very different compared to the case of Antarctica. Concerning Antarctic snow, following the pioneering shading experiment done by Jones et al. (2000) on snow from the coastal Antarctic site of Neumayer, numerous studies have investigated the release of $\mathrm{NO}_{\mathrm{x}}$ from the snow (Frey et al., 2014), but only two studies have reported on HONO snow emissions, and none of them examined together $\mathrm{HONO}$ and $\mathrm{NO}_{\mathrm{x}}$ emissions. Beine et al. (2006) reported small HONO fluxes $\left(3 \times 10^{7}\right.$ molecule $\left.\mathrm{cm}^{-2} \mathrm{~s}^{-1}\right)$ above the Browning Pass (coastal Antarctic) snowpack. However, the snow chemical composition at that site is very atypical, with a large presence of calcium (up to $4 \mathrm{ppm}$ ) attributed to the presence of a lot of rock outcrops at the site. As a consequence, even if nitrate is abundant (typically $200 \mathrm{ppb}$ in fresh snow and more than $1 \mathrm{ppm}$ in aged snow), the snow from that site appears to be weakly acidic and sometimes alkaline. Finally a few investigations of the vertical distribution of HONO were made at the South Pole (Dibb et al., 2004), but no fluxes were calculated. These previous Antarctic studies of HONO were carried out using either mist chambers (Dibb et al., 2002) or high-performance liquid chromatography techniques (Beine et al., 2006). These "wet chemical instruments" sample HONO on humid or aqueous surfaces followed by analysis of the nitrite ion. However, it is well known that many heterogeneous reactions lead to the formation of nitrite on similar surfaces (Gutzwiller et al., 2002; Liao et al., 2006). In addition to these chemical interferences, it is also known that HONO can decompose or be formed on various surfaces (Chan et al., 1976). That may have affected data when sampling lines of up to $30 \mathrm{~m}$ length were used for polar measurements (see, e.g., Beine et al., 2006).

Motivated by a strong need to extend investigations of the oxidation capacity of the lower atmosphere at the scale of the whole Antarctic continent, the OPALE (Oxidant Production over Antarctic Land and its Export) project was initiated at the end of 2010 in East Antarctica. The first OPALE campaign was conducted during austral summer 2010/2011 at the coastal site of Dumont D'Urville (Preunkert et al., 2012) and focused on $\mathrm{OH}$ and $\mathrm{RO}_{2}$ measurements (Kukui et al., 2012). During this first campaign, preliminary investigations of HONO were performed at the continental station of Concordia located at Dome C (denoted DC, $3233 \mathrm{~m}$ above sea level). In spite of the use of a long-path absorption photometer (LOPAP), thought to avoid all known artefacts, high mixing ratios of HONO were observed (from 5 to 59 pptv; Kerbrat et al., 2012). In the framework of the OPALE project, a second summer campaign (2011-2012) was conducted at Concordia with simultaneous measurements of $\mathrm{HONO}, \mathrm{NO}$, $\mathrm{NO}_{2}, \mathrm{OH}$, and $\mathrm{RO}_{2}$, which are discussed in a set of companion papers of which this is one.

The paper presented here focuses on HONO data gained during the second campaign at Concordia. It also reports on snow irradiation experiments conducted in the laboratory at the British Antarctic Survey (BAS) on surface snow samples collected at DC in order to quantify a possible photochemical snow source of HONO. This was done by measuring simultaneously $\mathrm{HONO}$ with the LOPAP, $\mathrm{NO}$, and $\mathrm{NO}_{2}$ with a two-channel chemiluminescence detector. From these data we crudely estimate the amount of HONO released from snow within the lower atmosphere at DC on the basis of the $\mathrm{NO}_{\mathrm{x}}$ snow emissions derived from the vertical gradient of atmospheric concentrations measured during the campaign by Frey et al. (2014). The derived values of the HONO flux were used in 1-D modelling calculations to evaluate the contribution of this snow source to the large HONO mixing ratios observed at Concordia. Finally, to evaluate a suspected possible interference of $\mathrm{HNO}_{4}$ on the $\mathrm{HONO}$ mixing ratio measured by the LOPAP, field experiments were conducted by heating sampled air prior to its introduction in the LOPAP device, heating being a convenient way to destroy $\mathrm{HNO}_{4}$. The selectivity to $\mathrm{HNO}_{4}$ and the response of the LOPAP during the heating events was also investigated in laboratory by mass spectrometry at the Paul Scherrer Institute (PSI).

\section{Methods and Site}

\subsection{HONO measurement method}

HONO was measured using a LOPAP which has been described in detail elsewhere (Heland et al., 2001; Kleffmann et al., 2002). In brief, after being sampled into a temperaturecontrolled stripping coil containing a mixture of sulfanilamide in a $1 \mathrm{~N} \mathrm{HCl}$ solution, $\mathrm{HONO}$ is derivatized into a coloured azo dye. The light absorption by the azo dye is measured in a long-path absorption tube by a spectrometer at $550 \mathrm{~nm}$ using an optical path length of $5 \mathrm{~m}$. The LOPAP did not have long sampling lines or inlet. The stripping coil was placed directly in the atmosphere being sampled. The 
LOPAP has two stripping coils connected in series to correct interferences. In the first coil (channel 1), HONO is trapped quantitatively together with a small amount of the interfering substances. Assuming that these interfering species are trapped in a similar amount in the second coil (channel 2 ), the difference between the signals resulting from stripping in each coil provides an interference-free HONO signal (Heland et al., 2001). Air was sampled at a flow rate of $1 \mathrm{~L} \mathrm{~min}^{-1}$, and the flow rate of the stripping solution was $0.17 \mathrm{~mL} \mathrm{~min}^{-1}$. Calibrations were performed every 5 days. Relative deviations of the calibration signal were of 3 and $9 \%$ at $3 \sigma$ for channel 1 and 2 , respectively. The quantification limit of the LOPAP instrument used in this study was as low as $1.5 \mathrm{pptv}$ (taken as $10 \sigma$ of all zero measurements done by sampling pure $\mathrm{N}_{2}$ ) with a time resolution of $9 \mathrm{~min}$. More details on the set-up of the LOPAP device in the fields can be found in Kerbrat et al. (2012). Similarly to the first campaign, the amount of interferences in the second coil was on average $9 \pm 7 \%$ of total signal (instead of $10 \pm 5 \%$ found by Kerbrat et al. (2012) in 2010/2011). The LOPAP was tested for numerous possible interfering species, including $\mathrm{NO}, \mathrm{NO}_{2}$, $\mathrm{HNO}_{3}$, and alkylnitrates. It was concluded that, when significant, the two-channel approach was able to well correct the HONO data (Kleffmann and Wiesen, 2008). However, it has to to be emphasized that no tests have been conducted for $\mathrm{HNO}_{4}$.

During the field campaign, HONO was occasionally sampled in the snow interstitial air by pumping air through a perfluoroalkoxy (PFA) tube (5 m long, $4 \mathrm{~mm}$ internal diameter) at a flow rate of $1 \mathrm{~L} \mathrm{~min}^{-1}$. In addition, to evaluate a possible influence of $\mathrm{HNO}_{4}$ on $\mathrm{HONO}$ measurements, field experiments were undertaken by heating air sampled through a $9 \mathrm{~m}$ long PFA tube. Tests were performed to evaluate potential loss or formation of HONO in the PFA tubes by running the LOPAP for $30 \mathrm{~min}$ with and without a tube connected to the inlet of the LOPAP, sampling air at the same height. In order to account for possible fast natural change of HONO mixing ratios, the test was repeated three times successively. The tests were carried out with ambient mixing ratios of $20 \mathrm{pptv}$ as encountered at midday on 23 December and $40 \mathrm{pptv}$ on the morning of 28 December. In the two cases losses of around 4 and 7 pptv were observed when using the 5 and $9 \mathrm{~m}$ long PFA tube, respectively. These losses will be considered in discussing HONO mixing ratios in interstitial air (see Sect. 3) or the interference of $\mathrm{HNO}_{4}$ (see Sect. 6).

\subsection{Field atmospheric measurements and snow samplings}

The second OPALE field campaign took place at Concordia located over the high East Antarctic Plateau from late November 2011 to mid-January 2012. Nitrous acid was measured $1 \mathrm{~m}$ above ground level, about $900 \mathrm{~m}$ south-southwest from the main Concordia station. Measurements that started 4 December were interrupted from 9 to 15 December, 16
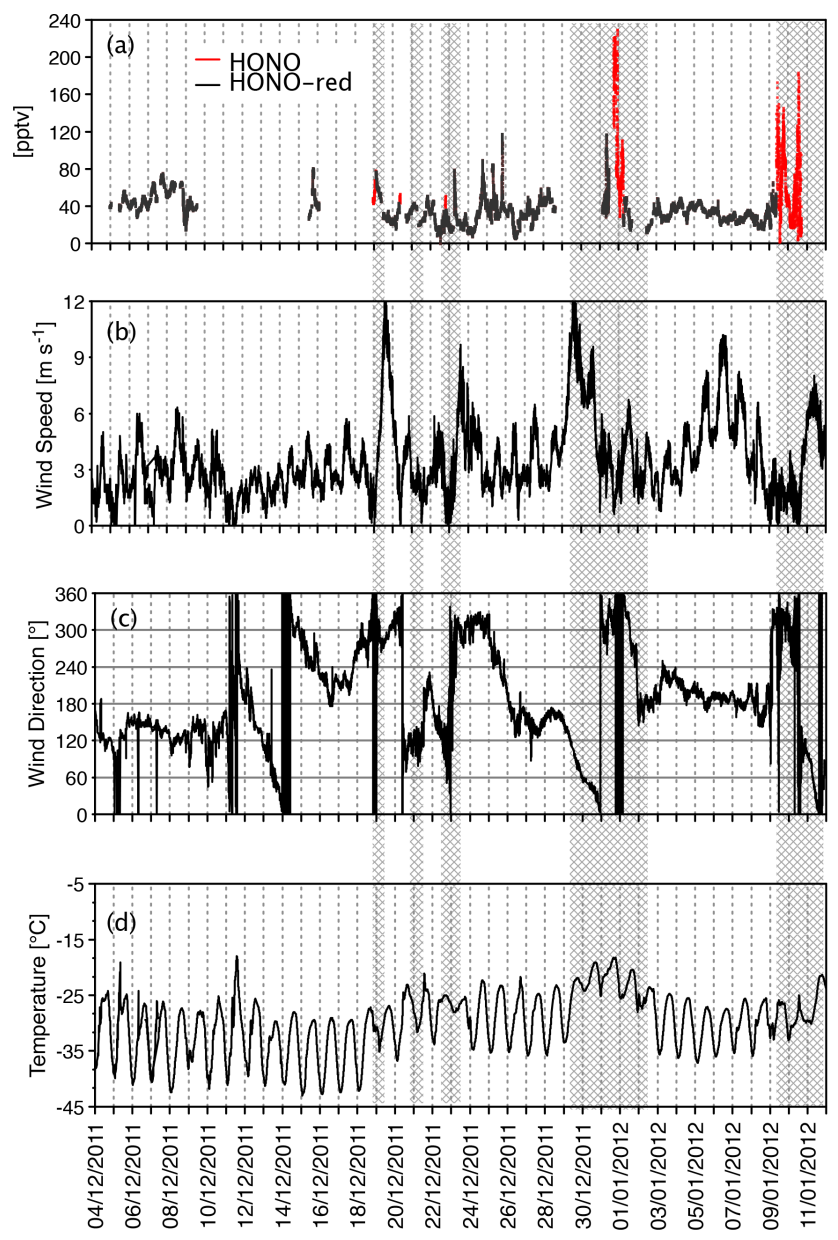

Figure 1. Summer 2011/2012 time series of HONO mixing ratios (1 min average) (a), wind conditions (b and $\mathbf{c}$ ) and temperatures (d) at Concordia. Red points of the HONO record refer to time periods during which contamination from the station was possible with the wind blowing from the north $\left(10^{\circ} \mathrm{W}\right.$ to $60^{\circ} \mathrm{E}$ sector; see Sect. 2.2). Grey backgrounds indicate time period of overcast weather.

to 18 December, and 28 to 30 December afternoon due to problems on the LOPAP device. On 1 and 2 January and from 10 to 13 January air measurements were stopped to measure HONO in snow interstitial air. During the measurement campaign, the main wind direction was from the southeast to southwest. Several episodes with wind blowing from the north $\left(10^{\circ} \mathrm{W}\right.$ to $60^{\circ} \mathrm{E}$ sector), i.e. from the direction of the station, were encountered (see the red points in Fig. 1). During some of these pollution events (31 December around 22:00 for instance), sharp peaks of HONO mixing ratios exceeding $100 \mathrm{pptv}$ were observed. These events were also detected in the $\mathrm{NO}_{\mathrm{x}}$ time series (Frey et al., 2014), with sharp peaks in the range of $100 \mathrm{ppbv}$ or more (120 ppbv on $31 \mathrm{De}-$ cember at around 22:00 for instance). The ratio of excess of HONO to excess of $\mathrm{NO}_{\mathrm{x}}$ during these events is close to $10^{-3}$. The ratios of $\mathrm{HONO} / \mathrm{NO}_{\mathrm{x}}$ reported by measurements made in traffic tunnels range from $3 \times 10^{-3}$ (Kirchstetter et 
al., 1996) to $8 \times 10^{-3}$ (Kurtenbach et al., 2001). When compared to ratios observed in tunnels, the lower ratio seen in the plume of the Concordia station when it reaches the sampling line is likely due the rapid photolytic destruction of HONO, whose lifetime is still as short as $20 \mathrm{~min}$ at the high solar zenith angles prevailing at DC around 22:00 in summer. In the following the data corresponding to red points reported in Fig. 1 were removed from the HONO data set.

Concurrent measurements of chemical species that are relevant for discussion include those of ozone, $\mathrm{NO}, \mathrm{NO}_{2}$, $\mathrm{OH}$, and $\mathrm{RO}_{2}$. Surface ozone was monitored simultaneously to HONO using UV absorption monitors (Thermo Electron Corporation model 49I) deployed at Concordia since 2007 (Legrand et al., 2009). Nitrogen oxides were determined by deploying a two-channel chemiluminescence detector (Bauguitte et al., 2012; Frey et al., 2013, 2014). The chemiluminescence detector measured $\mathrm{NO}$ in one channel and the sum of $\mathrm{NO}$, and $\mathrm{NO}$ originating from the photolytic conversion of $\mathrm{NO}_{2}$ in the other channel. As discussed by Frey et al. (2013), among various nitrogen oxides able to interfere on the photolytic conversion channel, only HONO has to be considered, leading to an overestimation of $\mathrm{NO}_{2}$ levels by less than $5 \%$. The radicals $\left(\mathrm{OH}\right.$ and $\left.\mathrm{RO}_{2}\right)$ were measured using chemical ionization mass spectrometry (Kukui et al., 2012, 2014). During the campaign the photolysis rate of HONO was documented using a Met-Con $2 \pi$ spectral radiometer equipped with a CCD detector and a spectral range from 285 to $700 \mathrm{~nm}$ (see details in Kukui et al., 2014).

Different surface snow samples were collected at DC and returned to the UK to be used in irradiation experiments (see Sects. 2.3 and 4). First, the upper $12 \mathrm{~cm}$ of snow was collected in December 2010. Second, the upper centimetre of snow corresponding to freshly drifted snow was collected 6 December 2011. The samples were characterized by their specific surface area (SSA). Measurements were performed using an Alpine snowpack specific surface area profiler, an instrument similar to that one described by Arnaud et al. (2011) based on the infrared reflectance technique. Briefly, a laser diode at $1310 \mathrm{~nm}$ illuminates the snow sample at nadir incidence angle, and the reflected hemispherical radiance is measured. The hemispherical reflectance at $1310 \mathrm{~nm}$ is related to the SSA using the analytical relationship proposed by Khokanovsky and Zege (2004). The SSA of the drifting snow is close to $26 \mathrm{~m}^{2} \mathrm{~kg}^{-1}$, and the upper $12 \mathrm{~cm}$ is $17 \mathrm{~m}^{2} \mathrm{~kg}^{-1}$. Such values appear to be close to typical DC values reported in the literature (Gallet et al., 2011), suggesting that lab experiments conducted on these snow samples (see Sect. 4) may be relevant to discuss at least qualitatively natural processes occurring at DC.

The upper surface snow (from 0 to $1 \mathrm{~cm}$, and from 0 to $12 \mathrm{~cm})$ at DC were also sampled and analysed for major anions and cations following working conditions reported in Legrand et al. (2013). For cations $\left(\mathrm{Na}^{+}, \mathrm{K}^{+}, \mathrm{Mg}^{2+}, \mathrm{Ca}^{2+}\right.$, and $\mathrm{NH}_{4}^{+}$), a Dionex 500 chromatograph equipped with a CS12 separator column was used. For anions, a Dionex 600 equipped with an AS11 separator column was run with a quaternary gradient of eluents $\left(\mathrm{H}_{2} \mathrm{O}, \mathrm{NaOH}\right.$ at 2.5 and $100 \mathrm{mM}$, and $\mathrm{CH}_{3} \mathrm{OH}$ ), allowing for the determination of inorganic species $\left(\mathrm{Cl}^{-}, \mathrm{NO}_{3}^{-}\right.$, and $\left.\mathrm{SO}_{4}^{2-}\right)$ as well as methanesulfonate $\left(\mathrm{CH}_{3} \mathrm{SO}_{3}^{-}\right)$. The acidity of samples can be evaluated by the ionic balance between anions and cations, with concentrations expressed in micro-equivalents per litre $\left(\mu \mathrm{Eq} \mathrm{L}^{-1}\right)$ :

$\left[\mathrm{H}^{+}\right]=\left[\mathrm{Cl}^{-}\right]+\left[\mathrm{NO}_{3}^{-}\right]+\left[\mathrm{SO}_{4}^{2-}\right]+\left[\mathrm{CH}_{3} \mathrm{SO}_{3}^{-}\right]$

$-\left[\mathrm{Na}^{+}\right]-\left[\mathrm{K}^{+}\right]-\left[\mathrm{Mg}^{2+}\right]-\left[\mathrm{Ca}^{2+}\right]-\left[\mathrm{NH}_{4}^{+}\right]$.

\subsection{Snow irradiation experiments conducted at BAS}

As discussed in Sect. 5, model simulations indicate that the production of $\mathrm{HONO}$ from the reaction of $\mathrm{OH}$ with $\mathrm{NO}$ is far too weak to explain observations at Concordia and that an additional light-driven HONO source is needed. To quantify a possible photochemical snow source of HONO, lab experiments were conducted at BAS by irradiating snow collected at $\mathrm{DC}$ and measuring gas-phase evolution of $\mathrm{NO}$ and $\mathrm{NO}_{2}$ with a two-channel chemiluminescence detector (Bauguitte et al., 2012) as deployed at Concordia (Frey et al., 2013, 2014) and HONO with the LOPAP that ran at Concordia during the 2010/2011 and 2011/2012 campaigns. A $20 \mathrm{~cm}$ long cylinder $(6 \mathrm{~cm}$ inner diameter) was filled with $\sim 120 \mathrm{~g}$ of snow inside an airtight glass reaction chamber (total length of $40 \mathrm{~cm}, 6 \mathrm{~cm}$ inner diameter) and put in a freezer of which the temperature was varied between -5 and $-35^{\circ} \mathrm{C}$. Further details on the characteristics of the reaction chamber can be found in Meusinger et al. (2014). The reaction chamber is maintained vertically in a freezer, and a $1000 \mathrm{~W}$ xenon arc lamp was put above the freezer. The snow was irradiated by directing the light axially along the tube through a quartz window, which makes up the top surface of the chamber. Chemically pure air was supplied to the chamber from a pure air generator (Ecophysics, PAG003) in which air is dried at $-15^{\circ} \mathrm{C}$. To match the relative humidity of the snow under investigation and limit metamorphism, this chemically pure air was passed through a cold trap at the temperature of the experiment. Note that, with this system and for temperatures above $-30^{\circ} \mathrm{C}$, no condensation trace was observed in the tube outflow of the chamber. The flow rate of zero air was $4.3 \mathrm{~L} \mathrm{~min}^{-1}$, while the detection systems sampled processed air at a rate of $2.0 \mathrm{~L} \mathrm{~min}^{-1}$ for $\mathrm{NO}_{\mathrm{x}}$ and $1.0 \mathrm{~L} \mathrm{~min}^{-1}$ for HONO. The overflow of $1.3 \mathrm{~L} \mathrm{~min}^{-1}$ was diverted through a flow meter to check for potential leaks. While the inlet line between the reaction chamber and the $\mathrm{NO}_{\mathrm{x}}$ analyser was several metres long, the length between the outlet of the reaction chamber and the LOPAP inlet was kept as short as possible (i.e. $25 \mathrm{~cm}$ ). To do so the inlet of the LOPAP was arranged in the freezer. The wavelength range of the $1000 \mathrm{~W}$ xenon arc lamp (Oriel Instruments) was $200-2500 \mathrm{~nm}$, modulated using filters with various cut-on points. The short residence time of $\mathrm{NO}_{2}(\sim 4 \mathrm{~s})$ in our small chamber prevents significant 

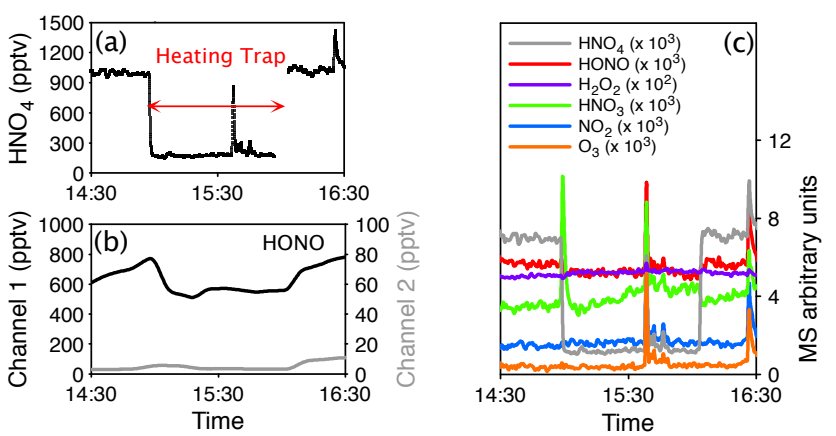

Figure 2. The experiment carried out at the PSI laboratory in order to investigate the interference of $\mathrm{HNO}_{4}$ on $\mathrm{HONO}$ measurements made with the LOPAP deployed during the two Concordia campaigns. Left: time traces of $\mathrm{HNO}_{4}$ (top) and of the two LOPAP channels (bottom). Time at which the heating trap was activated is shown with a red horizontal arrow. Right: intensities of $\mathrm{NO}_{2}, \mathrm{HONO}, \mathrm{HNO}_{3}, \mathrm{HNO}_{4}, \mathrm{O}_{3}$, and $\mathrm{H}_{2} \mathrm{O}_{2}$ traces as detected by the mass spectrometer (see Sect. 2.4). Heating the gas mixture to $100{ }^{\circ} \mathrm{C}$ leads to a sharp decrease in $\mathrm{HNO}_{4}$ and a small increase of $\mathrm{HNO}_{3}$ intensities. $\mathrm{O}_{3}$ and $\mathrm{H}_{2} \mathrm{O}_{2}$ remain stable, whereas a very small decrease of HONO is detectable.

photolysis of $\mathrm{NO}_{2}$ to occur during the experiments. Indeed, the $J_{\mathrm{NO}_{2}}$ of $2 \times 10^{-2} \mathrm{~s}^{-1}$ measured by Cotter et al. (2003) for a $1000 \mathrm{~W}$ xenon arc lamp, as also used in the present study, leads to a lifetime of $\mathrm{NO}_{2}$ with respect to photolysis of $50 \mathrm{~s}$ at the front of the snow block.

\subsection{Experiments performed at PSI to investigate a possible $\mathrm{HNO}_{4}$ interference on $\mathrm{HONO}$ measurements}

As will be discussed in Sect. 6, it may be difficult to reconcile typical mixing ratios of HONO measured $1 \mathrm{~m}$ above surface snow at Concordia with a reasonable estimate of the mixing ratio of $\mathrm{HONO}$ owing to emissions from snow due to snowpack photochemistry. It was suspected that $\mathrm{HNO}_{4}$ was detected and measured as HONO by the LOPAP instrument. As briefly reported below, a few experiments conducted at PSI indicate that the LOPAP instrument does have an interference for $\mathrm{HNO}_{4}$. Mixing ratios of $\mathrm{HNO}_{4}$ were not measured at Concordia, so the aim of the experiments described below was not to quantify the interference to enable correction of the Concordia HONO data, but to demonstrate that such an interference exits. The result of an experiment conducted under specific conditions is reported. A full characterization of the interference on $\mathrm{HONO}$ at various mixing ratios of $\mathrm{HNO}_{4}$ in the presence or absence of other trace gases present at DC is beyond the scope of this paper.

The interference of the LOPAP device was examined at PSI, where a gas-phase synthesis of $\mathrm{HNO}_{4}$ has been developed by irradiating a mixture of $\mathrm{NO}_{2} / \mathrm{H}_{2} \mathrm{O} / \mathrm{CO} / \mathrm{O}_{2} / \mathrm{N}_{2}$ at $172 \mathrm{~nm}$ (Bartels-Rausch et al., 2011). By-products of the synthesis are $\mathrm{HONO}, \mathrm{HNO}_{3}$, and $\mathrm{H}_{2} \mathrm{O}_{2}$. The synthesis gas was fed into the sampling unit of the LOPAP, and the resulting LOPAP signals in the presence and absence of $\mathrm{HNO}_{4}$ were compared. Heating the synthesis gas to a temperature of $100^{\circ} \mathrm{C}$ prior to sampling by the LOPAP allowed selective removal of $\mathrm{HNO}_{4}$ from the gas mixture. The mixing ratios of $\mathrm{HONO}, \mathrm{NO}_{2}, \mathrm{H}_{2} \mathrm{O}_{2}$, and $\mathrm{O}_{3}$ that are present in the synthesis gas were independently monitored with a chemical ionization mass spectrometer (CIMS), which was calibrated by using several analysers as detailed in Ulrich et al. (2012). An example of the mixing ratios of $\mathrm{HNO}_{4}$ and $\mathrm{HONO}$ measured by CIMS and of the corresponding LOPAP signals in channel 1 and 2 is shown in Fig. 2. The relative amount of HONO (780 pptv) and $\mathrm{HNO}_{4}(1000$ pptv) observed in the synthetized mixture (prior heating) is typical for this synthesis (Bartels-Rausch et al., 2011). The experiment shows the response of the signals when the heating trap used to decompose $\mathrm{HNO}_{4}$ is applied. As seen in Fig. 2, the mixing ratios of $\mathrm{HONO}, \mathrm{NO}_{2}, \mathrm{H}_{2} \mathrm{O}_{2}$, or $\mathrm{O}_{3}$ that may influence the response of the LOPAP instrument did not change upon the thermal decomposition of $\mathrm{HNO}_{4}$. A decrease of the LOPAP signal in channel 1 is observed during the heating event, indicating that $1 \mathrm{ppbv}$ of $\mathrm{HNO}_{4}$ corresponds to a signal in the LOPAP of 150 pptv. Examination of the signals of the two LOPAP channels (Fig. 2) suggests that $\mathrm{HNO}_{4}$ has been efficiently sampled in the first channel. It is well known that $\mathrm{HNO}_{4}$ efficiently decomposes to $\mathrm{NO}_{2}^{-}$in acidic solutions (Regimbal and Mozurkewich, 1997), just like HONO does in the LOPAP sample unit. Based on the identical hydrolysis products, one might thus expect a rather large interference. The high sampling efficiency of $\mathrm{HONO}$ and potentially $\mathrm{HNO}_{4}$, both of which have similar partitioning coefficients to acidic solutions, is driven by the fast reaction of their hydrolysis product $\left(\mathrm{NO}_{2}^{-}\right)$with the reagents in the sampling solution of the LOPAP instrument. A full characterization of the interference by $\mathrm{HNO}_{4}$ (its behaviour and quantification over a large range of concentrations, in the presence or absence of other gases) is needed to improve the use of the LOPAP in very cold atmospheres. We suggest a detailed investigation of LOPAP instrument response to different compositions of test gas mixture (i.e. with larger mixing ratios of $\mathrm{H}_{2} \mathrm{O}_{2}$ ), and with an investigation of the potentially complex (non-linear) chemistry of sampled gases. At this stage we can only exclude an oxidation of the dye used in the LOPAP instrument by $\mathrm{HNO}_{4}$, as careful inspection of the absorption spectrum of the LOPAP dye reveals no significant change during heating. Assuming the interference of $\mathrm{HONO}$ signal by $\mathrm{HNO}_{4}$ to be linear, one would expect an interference of $\sim 15 \mathrm{pptv}$ in the HONO signal due to a mixing ratio of 100 pptv of $\mathrm{HNO}_{4}$. Given the absence of measurements of the mixing ratio of $\mathrm{HNO}_{4}$ at Concordia, further experiments were conducted in the field at Concordia to directly estimate this interference as detailed in Sect. 6. 

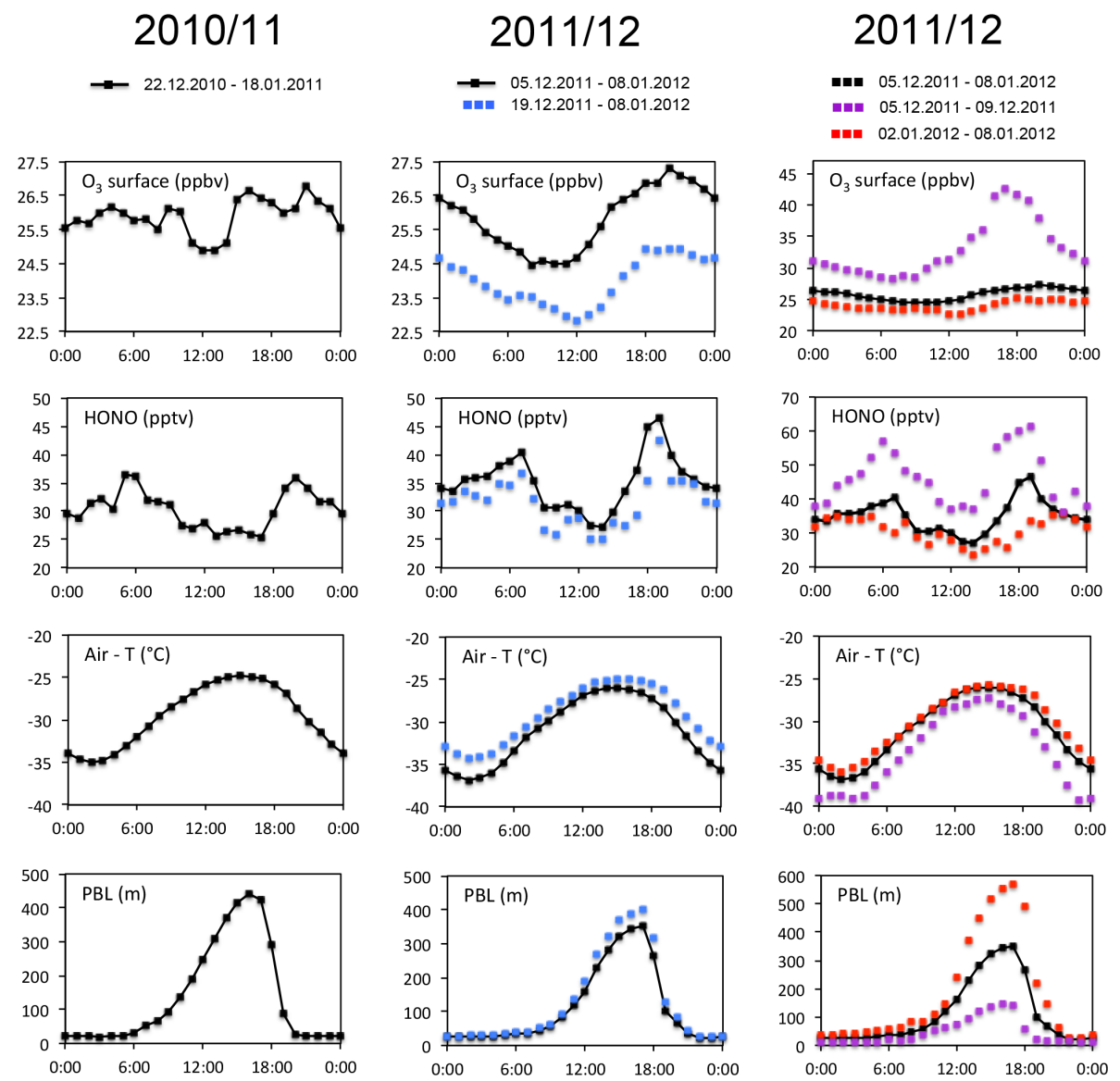

Figure 3. Left and middle: from top to bottom, diurnal changes of surface ozone mixing ratio, HONO mixing ratio, air temperature, and PBL height simulated by the MAR model (see Sect. 5) at Concordia over the entire period of measurements in 2010/2011 (left) and 2011/20112 (middle) (black dots). The blue dots reported for the 2011/2012 summer correspond to the period between 19 December 2011 and 8 January 2012. Right: Same as left and middle but for the entire 2011/2012 period (black dots), at the beginning (early December, violet dots), and the end (red dots) of the period. Note the use of different vertical scales for right compared to left and middle panels.

\section{HONO observations at Concordia}

Removing data suspected to have been impacted by pollution from station activities (see Sect. 2.2), a 1 min average mixing ratio of $35 \pm 14 \mathrm{pptv}$ is observed in December 2011/January 2012 compared to $28 \pm 12$ pptv measured by Kerbrat et al. (2012) for December 2010/January 2011.

The mean diurnal cycles of surface ozone, HONO, air temperature, and the planetary boundary layer (PBL) height simulated by the regional atmospheric MAR model (Modèle Atmosphérique Régional) are reported and compared for the two summers in Fig. 3. In the polar region, the strong static stability of the atmosphere often inhibits vertical mixing of surface emissions between the surface boundary layer and the rest of the atmosphere. At DC, the surface absorbs solar radiations during the day, heats the lower atmosphere, and generates positive buoyancy that is responsible for an increase of turbulent kinetic energy and the subsequent increase of the boundary layer height seen in Fig. 3. This boundary layer is referred to as the "daytime boundary layer". The surface cooling after 17:00 generates negative buoyancy near the surface. A new boundary layer referred as the "night-time boundary layer" develops but remains less active than the previous daytime boundary layer. The collapse of the boundary layer after 17:00 seen in Fig. 3 is in fact the representation of the transition between the daytime and night-time boundary layer.

The two mean summer ozone records indicate a drop of 1 to 2 ppbv around midday compared to early morning and evening values (Fig. 3). This small surface ozone change over the course of the day at DC has already been observed by Legrand et al. (2009), who attributed it to the increase of the PBL height in the afternoon that counteracts a local photochemical production of $\mathrm{O}_{3}$ in the range of $0.2 \mathrm{ppbv} \mathrm{h}^{-1}$ during daytime.

Consistently with the previous 2010/2011 measurements from Kerbrat et al. (2012), the HONO mixing ratios exhibit a well-marked diurnal variation characterized by morning (around 05:00-07:00) and evening (around 20:00) maxima 
exceeding midday values by some $10 \mathrm{pptv}$. Therefore, in addition to an expected more efficient photolysis of HONO during the day, the increase of the daytime boundary layer may also accounts for the observed decreased HONO mixing ratios during the day in spite of a more active snow source (see discussions in Sect. 5). Such a diurnal variability characterized by noon minimum was also observed for $\mathrm{NO}_{\mathrm{x}}$ by Frey et al. (2013) and attributed to the interplay between photochemical snow source and boundary layer dynamics.

As shown in Fig. 3, the larger HONO mixing ratios calculated for 2011/2012 (diurnal mean of $35 \pm 5.0 \mathrm{pptv}$ ) with respect to the 2010/2011 ones (diurnal mean of $30.5 \pm 3.5$ pptv) concern both the midday minimum and the morning/evening maxima. The difference between the two summers, however, is reduced when the first week of measurements undertaken in December 2011 is removed with a lower diurnal mean $(31.7 \pm 4.3$ instead of $35 \pm 5$ pptv over the entire measurement period; see the blue points in Fig. 3). The case of the beginning of December 2011 with respect to the rest of the summer 2011/2012 is highlighted in Fig. 3. It can be seen that the far thinner PBL height of early December (maximum of 145 instead of $350 \mathrm{~m}$ over the entire period) may have led to a more confined HONO production (see violet points in Fig. 3). Note also the relatively high ozone mixing ratios at that time $(33 \pm 4 \mathrm{ppbv}$ in early December instead of $26 \pm 1 \mathrm{ppbv}$ over the entire period). Conversely, at the end of the period the PBL became thicker (maximum of $570 \mathrm{~m})$ and the mixing ratios of ozone $(24 \pm 1 \mathrm{ppbv})$ and nitrous acid $(31 \pm 4 \mathrm{pptv})$ were lower than on average (see red points in Fig. 3). Finally, in early December 2011 the highest daily average mixing ratio of HONO observed, on 7 and 8 December (56 pptv, Fig. 1), corresponds not only to a thin PBL but also to lowest value of total ozone column (260 Dobson units (DU) instead of $296 \pm 20$ DU on average) measured by the SAOZ (Système d'Analyse par Observation Zénitale) at Concordia. Similarly, during the 2010/2011 campaign the highest values reported at the end of the campaign (44 pptv from 15 to 18 January) by Kerbrat et al. (2012) correspond to the lowest value of total ozone column (270 instead of $303 \pm 17 \mathrm{DU}$ on average). It therefore seems that HONO mixing ratios measured at $1 \mathrm{~m}$ at DC are also sensitive to the UV actinic flux reaching the surface. This link between stratospheric ozone and photochemistry of snow at the ground is discussed in more detail by Frey et al. (2014).

It therefore seems that one of the main causes of the difference between the 2011/2012 and 2010/2011 mean summer values is the slightly different atmospheric vertical stability conditions experienced over the different sampling times of the two summers, with an earlier HONO sampling in December 2011 than in December 2010 leading to higher HONO mixing ratios in a very thin and stable boundary layer. In conclusion, this second study of HONO confirms the abundance of this species in the lower atmosphere at DC with a typical mean mixing ratio of $30 \mathrm{pptv}$ from mid-December to mid-January.

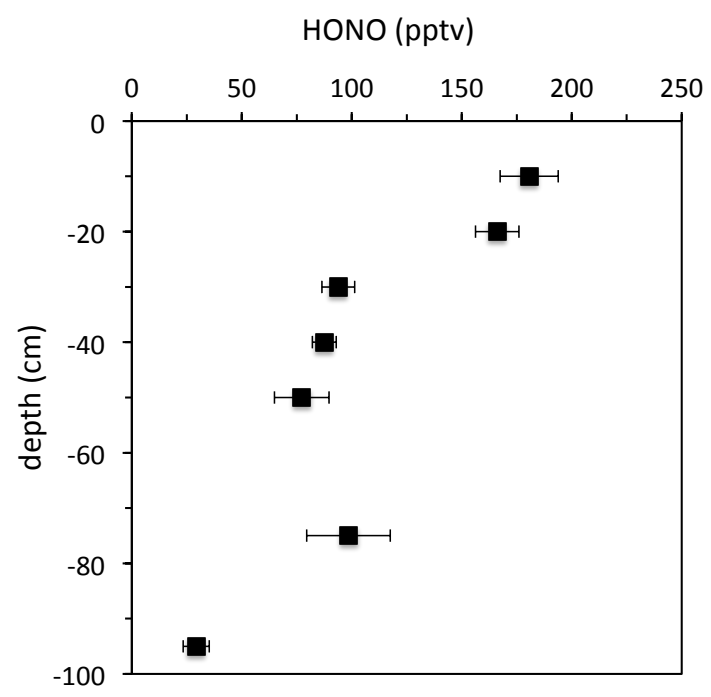

Figure 4. Firn air mixing ratios of HONO down to $1 \mathrm{~m}$ depth measured at DC at 13 January 2012.

As already discussed by Kerbrat et al. (2012) (see also Sect. 5), the existence of a large photochemical source of HONO in the snowpack is needed to explain these large mixing ratios of HONO measured above the snowpack. Measurements of the mixing ratio of HONO were therefore performed in snow interstitial air at different depths. From the top few centimetres of the snowpack down to $75 \mathrm{~cm}$ depth, mixing ratios of HONO in snowpack interstitial air tended to exceed those in the air above the snowpack, supporting the existence of a snow source of HONO (Fig. 4). However, given the interference of $\mathrm{HNO}_{4}$ on $\mathrm{HONO}$ mixing ratio data as discussed in Sect. 6, it is difficult to use the observed vertical gradient of HONO mixing ratio to derive an estimate of emission of HONO from the snowpack. Indeed, typical values of $\mathrm{HNO}_{4}$ mixing ratios are available in lower atmosphere of the Antarctic Plateau (Sect. 6) but not yet in snow interstitial air. Also it remains difficult to accurately estimate the production rate of $\mathrm{HNO}_{4}$ in snow interstitial air from the reaction of $\mathrm{NO}_{2}$ with $\mathrm{HO}_{2}$ versus its uptake on natural ice surface.

To confirm the snowpack as a source of HONO (and as detailed in the following section), we carried out a laboratory experiment to evaluate the ratio of $\mathrm{HONO}$ to $\mathrm{NO}_{\mathrm{x}}$ released from natural surface snows collected at DC under controlled laboratory conditions (i.e. wavelength of light, temperature, snow specific area) to estimate the HONO snow emission flux relative to the snow emission flux of $\mathrm{NO}_{\mathrm{x}}$ for the same snowpack as derived from the atmospheric concentration vertical gradient measured during the campaign by Frey et al. (2014). 
Table 1. Results of irradiation experiments performed at the BAS laboratory on three different surface snows collected at DC. S1 and S2 are upper surface snows collected between 0 and $1 \mathrm{~cm}$; S3 is the surface snow collected between 0 and $12 \mathrm{~cm}$ depth. The acidity is calculated by checking the balance between anions and cations (see Sect. 2.2). DL refers to detection limit, and N.C. means non-calculated value.

\begin{tabular}{llllrrrrr}
\hline $\begin{array}{l}\text { Snow } \\
\text { type }\end{array}$ & $\begin{array}{l}\text { Date } \\
\text { in 2013 }\end{array}$ & $\begin{array}{l}\text { Wavelengths } \\
\lambda>\end{array}$ & $T\left({ }^{\circ} \mathrm{C}\right)$ & $\begin{array}{r}\mathrm{HONO} \\
(\mathrm{pptv})\end{array}$ & $\begin{array}{r}\mathrm{NO}_{\mathrm{x}} \\
(\mathrm{pptv})\end{array}$ & $\begin{array}{r}\mathrm{HONO} / \\
\mathrm{NO}_{\mathrm{x}}\end{array}$ & $\begin{array}{r}\mathrm{NO}_{3}^{-} \\
(\mathrm{ppb})\end{array}$ & $\begin{array}{r}\mathrm{H}^{+} \\
\left(\mu \mathrm{Eq} \mathrm{L}^{-1}\right)\end{array}$ \\
\hline $\mathrm{S} 1$ & 23 Jan & $295 \mathrm{~nm}$ & -15 & $117 \pm 5$ & $137 \pm 20$ & $0.85 \pm 0.1$ & 1428 & 29.4 \\
$\mathrm{~S} 1$ & 24 Jan & $295 \mathrm{~nm}$ & -15.5 & $120 \pm 3$ & $129 \pm 16$ & $0.93 \pm 0.1$ & 1428 & 29.4 \\
$\mathrm{~S} 1$ & 24 Jan & $320 \mathrm{~nm}$ & -16 & $47 \pm 1$ & $67 \pm 12$ & $0.70 \pm 0.1$ & 1428 & 29.4 \\
$\mathrm{~S} 1$ & 24 Jan & $385 \mathrm{~nm}$ & -16 & $<3$ & $<\mathrm{DL}$ & $\mathrm{N} . \mathrm{C}$. & 1428 & 29.4 \\
$\mathrm{~S} 2$ & $23 \mathrm{Apr}$ & $295 \mathrm{~nm}$ & -13 & $124 \pm 1$ & $162 \pm 14$ & $0.77 \pm 0.1$ & 1344 & 24.0 \\
$\mathrm{~S} 2$ & $23 \mathrm{Apr}$ & $295 \mathrm{~nm}$ & -22.5 & $86 \pm 3$ & $167 \pm 40$ & $0.52 \pm 0.1$ & 1344 & 24.0 \\
$\mathrm{~S} 2$ & $23 \mathrm{Apr}$ & $295 \mathrm{~nm}$ & -34 & $56 \pm 1$ & $210 \pm 50$ & $0.27 \pm 0.2$ & 1344 & 24.0 \\
$\mathrm{~S} 3$ & $25 \mathrm{Apr}$ & $295 \mathrm{~nm}$ & -21 & $15 \pm 2$ & $47 \pm 27$ & $0.32 \pm 0.15$ & 157 & 4.0 \\
\hline
\end{tabular}

\section{Lab experiments on natural snow collected at DC}

Table 1 summarizes the results of experiments conducted at BAS by irradiating surface snows collected at DC (see Sect. 2.3). $\mathrm{NO}_{\mathrm{x}}$ and $\mathrm{HONO}$ are produced when snow is irradiated. Several laboratory experiments were conducted to investigate the wavelength, temperature, and snow chemical composition dependence of HONO release from snow. Similar to previous laboratory experiments conducted by Cotter et al. (2003) on surface snows collected in coastal Antarctica, the $\mathrm{NO}_{\mathrm{x}}$ release is found to halve when the optical filter in the front of the irradiation lamp (cut off for $<295 \mathrm{~nm}$ ) is replaced by a cut-off filter for illumination wavelength smaller than $320 \mathrm{~nm}$ (Table 1). Cotter et al. (2003) demonstrated no measurable emission of $\mathrm{NO}_{\mathrm{x}}$ from the snow when illuminated with a lamp with wavelengths shaded below $345 \mathrm{~nm}$, which is consistent with $\mathrm{NO}_{3}^{-}$photolysis. Figure 5 illustrates the wavelength dependence of HONO release, showing the effect of insertion of a filter with different cut-off points. Similarly to the $\mathrm{NO}_{\mathrm{x}}$, the HONO release is decreased by a factor of 2 when inserting the filter at $320 \mathrm{~nm}$ and becomes insignificant at $385 \mathrm{~nm}$ (Table 1).

While the observed wavelength dependency of the $\mathrm{NO}_{\mathrm{x}}$ release supports the hypothesis that the photolysis of nitrate present in snow is the major source of released $\mathrm{NO}_{\mathrm{x}}$ (via its major channel: $\mathrm{NO}_{3}^{-}+h v \rightarrow \mathrm{NO}_{2}+\mathrm{O}^{-}$), for $\mathrm{HONO}$ it is still unclear whether the nitrate photolysis efficiently produces directly $\mathrm{HONO}$ from hydrolysis of $\mathrm{NO}_{2}^{-}$produced by the second channel of the nitrate photolysis $\left(\mathrm{NO}_{3}^{-}+h v \rightarrow \mathrm{NO}_{2}^{-}+\right.$ $\mathrm{O}$ ) or $\mathrm{HONO}$ is secondarily produced from $\mathrm{NO}_{2}$ (Villena et al., 2011). Indeed, lab experiments conducted on nitratedoped ice suggest that the first channel is a factor of 8-9 more efficient than the second one. It is suspected that the HONO production may be significantly higher than it is when considering this second channel since the $\mathrm{NO}_{2}$ produced by the first channel may subsequently act as a precursor of HONO. The wavelength dependency of HONO release observed during previous experiments does not, however, help to separate the primary and secondary source of HONO during irradia-

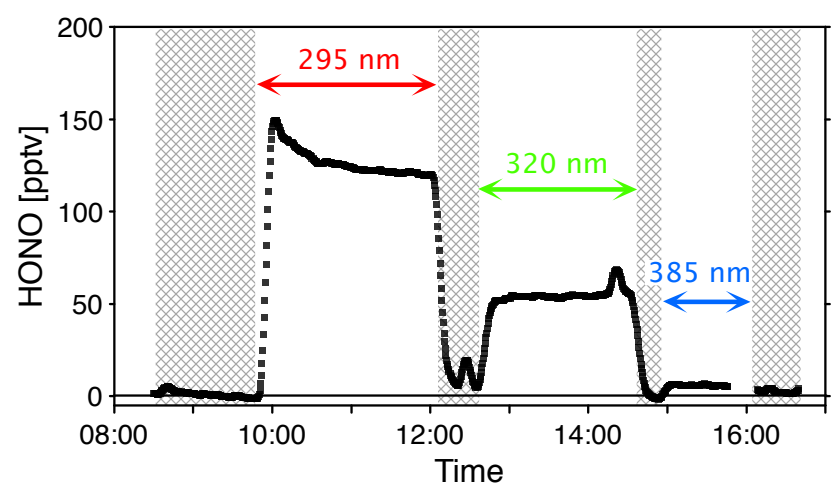

Figure 5. Photochemical release of HONO from a surface snow collected at DC when irradiating it at a temperature of $-16^{\circ} \mathrm{C}$ (see Table 1) and inserting filters with cut-off points at 295, 320, and $385 \mathrm{~nm}$ on the xenon arc lamp (see Sect. 4). Vertical grey bands correspond to periods over which the lamp was switched off.

tion since they were done with chemically pure air and, when placing the cut-off filter at $385 \mathrm{~nm}$, we suppress the primary source of $\mathrm{HONO}$ as well as $\mathrm{NO}_{2}$ that is needed for secondary HONO production.

Among possible secondary productions it is generally accepted that the reduction of $\mathrm{NO}_{2}$ on photo-sensitized organic material like humic acid (George et al., 2005; Bartels-Rausch et al., 2010) would proceed more efficiently than the disproportionation reaction of $\mathrm{NO}_{2}\left(2 \mathrm{NO}_{2}+\mathrm{H}_{2} \mathrm{O} \rightarrow \mathrm{HONO}\right.$ $+\mathrm{HNO}_{3}$ ) (Finlayson-Pitts et al., 2003). As discussed by Grannas et al. (2007), the relevance of this secondary production was supported even for Antarctica by the significant presence of dissolved fulvic acid reported for Antarctic snow (26-46 ppb C) by Calace et al. (2005). However, the previously assumed ubiquitous presence of organics in polar snow that is needed to reduce $\mathrm{NO}_{2}$ into $\mathrm{HONO}$ was recently reviewed by Legrand et al. (2013), who found that organics (and humic acids) are far less abundant in Antarctica compared to Greenland or midlatitude glaciers like the Alps. For instance, the typical dissolved organic content of 
summer surface snow is only $10-27 \mathrm{ppb}$ C at DC (Legrand et al., 2013) as opposed to $110 \pm 45 \mathrm{ppb} C$ at Summit and $300 \mathrm{ppbC}$ in the Alps. Furthermore, recent HULIS (humiclike substance) measurements of surface snows collected at DC do not confirm the previously observed abundance ( 2 instead of $26-46 \mathrm{ppb}$ C). From lab experiments conducted by irradiating ice films containing humic acid in the presence of $\mathrm{NO}_{2}$, Bartels-Rausch et al. (2010) derived production rates of $\mathrm{HONO}$ from $\mathrm{NO}_{2}$. From that, the authors roughly estimated light-driven HONO fluxes of $10^{13}$ molecules $\mathrm{m}^{-2} \mathrm{~s}^{-1}$ from snow-covered surface area, assuming the presence of 100 pptv $\mathrm{NO}_{2}$ in the snow interstitial air and a concentration of $10 \mathrm{ppbC}$ of humic acid in snow. Keeping in mind uncertainties in extrapolating lab experiments to conditions relevant to the lower atmosphere at $\mathrm{DC}$, with typical $\mathrm{NO}_{2}$ mixing ratios of 1 to $10 \mathrm{ppbv}$ in interstitial air at $10 \mathrm{~cm}$ below the surface at DC (Frey et al., 2014), the presence of $2 \mathrm{ppbC}$ of HULIS in snow may still lead to a significant $\mathrm{HONO}$ production from $\mathrm{NO}_{2}$ at the site. If HULIS are located at the surface of snow grains, much more than $2 \mathrm{ppb} C$ of HULIS would be available to react with $\mathrm{NO}_{2}$ present in interstitial air of the snowpack to produce HONO.

Irradiation experiments with insertion of the filter at $295 \mathrm{~nm}$ were conducted at temperatures ranging from 240 to $260 \mathrm{~K}$. As seen in Table 1, whereas the $\mathrm{NO}_{\mathrm{x}}$ release was found to be temperature independent (as previously shown by Cotter et al., 2003), a large dependence is found for HONO with an increase by a factor of 2.2 when the temperature of snow is increased from 240 to $260 \mathrm{~K}$. A temperature dependence of the HONO emissions is expected since the partition coefficient of HONO between ice and air increases by a factor of 5.8 between 240 and $260 \mathrm{~K}$ (Crowley et al., 2010). As a consequence the HONO to NOx release is smaller at $240 \mathrm{~K}$ than at $260 \mathrm{~K}$. For the example of the surface snow reported in Table 1, this ratio steadily increases from 0.3 at $240 \mathrm{~K}$, to 0.5 at $250 \mathrm{~K}$, to 0.8 at $260 \mathrm{~K}$.

In Table 1 we report experiments with DC snow containing 160 to $1400 \mathrm{ppb}$ of nitrate. As expected higher nitrate content leads to higher snow release of $\mathrm{NO}_{\mathrm{x}}$ and $\mathrm{HONO}$, but the increase of $\mathrm{HONO}$ is larger than $\mathrm{NO}_{\mathrm{x}}$. For instance, at a temperature close to $-20^{\circ} \mathrm{C}$, the first upper centimetre of surface snow releases almost twice as much HONO compared $\mathrm{NO}_{\mathrm{x}}$ as the snow collected from the surface to $12 \mathrm{~cm}$ depth. The more acidic character of the snow collected in the upper first centimetre compared to that collected down to $12 \mathrm{~cm}$ below the surface (see Table 1) may favour the release of a weak acid species like HONO.

\section{Model calculations}

Observed atmospheric mixing ratios were compared with steady-state calculations made by considering major gasphase sources and sinks of HONO. The major sink of HONO is its photolysis. The photolysis rate constant $\left(J_{\mathrm{HONO}}\right)$ was
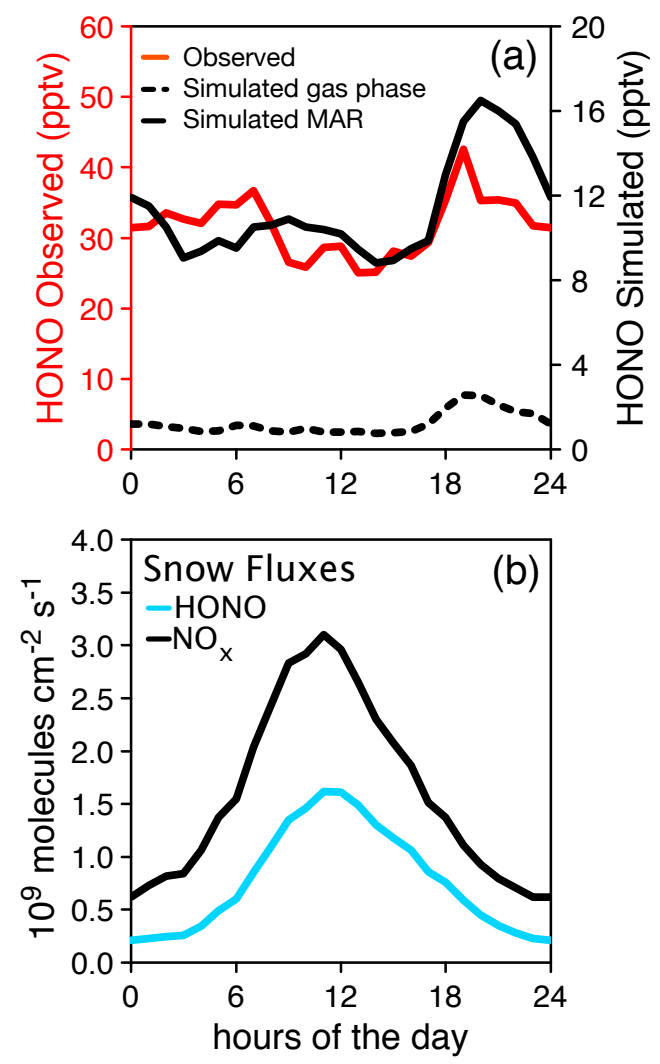

Figure 6. Top: measured (red line) versus simulated (black lines) (see Sect. 5) diurnal cycles of HONO mixing ratio at $1 \mathrm{~m}$ height. Note the use of a different vertical scale for observations (left) and simulations (right). The black dashed line is the simulation made when considering only the gas-phase production of HONO from $\mathrm{NO}$ (without snow emissions). Bottom: diurnal $\mathrm{NO}_{\mathrm{x}}$ snow source derived from field observations at Concordia (Frey et al., 2014) together with an estimated emission of HONO from snow based on laboratory snow irradiation experiments (see Sect. 4).

measured with a $2 \pi$ spectroradiometer (see Sect. 2.2). The value of $J_{\mathrm{HONO}}$ was calculated for light from $4 \pi$ steradians from the downwelling value of $J_{\text {HONO }}$ measured over $2 \pi$ steradians by assuming a surface albedo of 0.95 , a typical value for regions covered by dry snow and with a wavelength shorter than $400 \mathrm{~nm}$ (Hudson et al., 2006; France et al., 2011). The main gas-phase production of HONO is the reaction of NO with $\mathrm{OH}$ radicals. Steady-state calculations indicate that under noon conditions encountered at DC (a $J_{\mathrm{HONO}}$ value of $3.7 \times 10^{-3} \mathrm{~s}^{-1}, 5 \times 10^{6} \mathrm{OH} \mathrm{rad} \mathrm{cm}^{-3}$ (Kukui et al., 2014), and 50 pptv of NO (Frey et al., 2014)) a HONO mixing ratio of $1 \mathrm{pptv}$ is expected. The steady-state calculated diurnal HONO profile (Fig. 6) suggests a HONO maximum of $2.5 \mathrm{pptv}$ at 19:00 due to the presence of a maximum of 120 pptv of NO (Frey et al., 2014).

Another gas-phase source of HONO was recently proposed by $\mathrm{Li}$ et al. (2014) via reaction of the $\mathrm{HO}_{2}\left(\mathrm{H}_{2} \mathrm{O}\right)$ 
complex with $\mathrm{NO}_{2}$ :

$\mathrm{HO}_{2}+\mathrm{NO}_{2} \rightarrow \mathrm{HO}_{2} \mathrm{NO}_{2}$,

$\mathrm{HO}_{2}+\mathrm{H}_{2} \mathrm{O} \leftrightarrow \mathrm{HO}_{2}\left(\mathrm{H}_{2} \mathrm{O}\right)$,

$\mathrm{HO}_{2}\left(\mathrm{H}_{2} \mathrm{O}\right)+\mathrm{NO}_{2} \rightarrow \mathrm{HONO}+$ other products.

Reaction of the $\mathrm{HO}_{2}\left(\mathrm{H}_{2} \mathrm{O}\right)$ complex with $\mathrm{NO}_{2}$ was first suggested by Sander and Peterson (1984) to explain the observation of a linear dependence of the effective rate constant of the reaction of $\mathrm{HO}_{2}$ with $\mathrm{NO}_{2}$ on the concentration of water vapour in the temperature range 275-298 K. Assuming a reaction mechanism (Reactions R2-4), Sander and Peterson (1984) derived temperature dependence for the effective third-order rate constant of the reaction $\mathrm{HO}_{2}+\mathrm{NO}_{2}+\mathrm{H}_{2} \mathrm{O}$, $k_{4}^{\mathrm{III}}(T)$, with $k_{4}^{\mathrm{III}}(T)$ representing the product $k_{4} \times \mathrm{K}_{3}$, where $k_{4}$ is the bimolecular rate constant for reaction $\mathrm{HO}_{2}\left(\mathrm{H}_{2} \mathrm{O}\right)$ with $\mathrm{NO}_{2}$ and $\mathrm{K}_{3}$ is the equilibrium constant for Reaction (3). The possible contribution of Reaction (4) to form HONO at Concordia was evaluated by assuming a unity yield of HONO for the Reaction (4). The rate constant $k_{4}(T)$ in the temperature range $275-298 \mathrm{~K}$ was estimated from the $k_{4}^{\mathrm{III}}(T)$ data of Sander and Peterson (1984) using recent recommendations for $\mathrm{K}_{3}(T)$ and $k_{2}(T)$ from Sander et al. (2011): $k_{4}(T)=k_{4}^{\mathrm{III}}(T) / \mathrm{K}_{3}(T) \times k_{2}(T) / k_{2}(T)^{\mathrm{Sander}}$, where $k_{2}(T)^{\text {Sander }}$ are data from Sander and Peterson (1984). The values of $k_{4}(T)$ at low temperatures encountered at Concordia were obtained by extrapolating the $k_{4}(T) / k_{2}(T)$ data from Sander and Peterson (1984) and assuming a logarithmic dependence of $k_{4}(T) / k_{2}(T)$ on $1 / T$, similar to the reaction of $\mathrm{HO}_{2}\left(\mathrm{H}_{2} \mathrm{O}\right.$ ) with $\mathrm{HO}_{2}$ (Sanders et al., 2011). The resulting dependence $\left(k_{4}(T) / k_{2}(T)=10^{-1505.3 / T(K)+5.4}\right)$ predicts significantly lower water enhancement effect at low temperature $\left(k_{4} / k_{2}=0.12\right.$ at $240 \mathrm{~K}$ compared to 2.2 at $\left.298 \mathrm{~K}\right)$. Using these $k_{4}$ values and observations of $\mathrm{OH}, \mathrm{NO}, \mathrm{HO}_{2}, \mathrm{NO}_{2}$, and $\mathrm{H}_{2} \mathrm{O}$, the low temperatures encountered at Concordia render the formation of HONO from Reaction (4) negligible. This hypothetical HONO source would contribute $10-20 \%$ of the $\mathrm{HONO}$ production from the reaction $\mathrm{OH}+\mathrm{NO}$ and would result in less than $1 \%$ of the measured HONO.

An additional source of HONO is obviously required to account for observed mixing ratios of a few tens of pptv. On the basis of laboratory experiments presented in Sect. 4, we examine to what extent the snow photochemical source of HONO accounts for atmospheric observations of HONO at Concordia. Simulations were made with a numerical 1-D box model that considers, in addition to the above-mentioned gas-phase sources and sinks of HONO, a flux from the snow and its diffusive vertical transport. The turbulent diffusion coefficients $\left(K_{z}\right)$ were calculated by the regional atmospheric MAR model. Since cloud cover is responsible for an increase of around $50 \%$ of the downwelling long-wave radiations in summer at DC, when the cloud cover is underestimated, the surface heat budget is not well simulated, and this strongly impacts the turbulence simulated by the model. We therefore performed calculations only for days with clear sky conditions (see Fig. 1).

We used the MAR model with a horizontal resolution of $20 \mathrm{~km}$ centred at Concordia; a top level is at $1 \mathrm{hPa}$ with 100 vertical levels. The vertical resolution is $0.9 \mathrm{~m}$ up to $23 \mathrm{~m}$ above the surface, and it decreases upward. MAR $K_{z}$ values are linearly interpolated to the vertical grid used in our 1-D simulation, spacing $0.1 \mathrm{~m}$ from the ground to $5 \mathrm{~m}, 0.2 \mathrm{~m}$ from 5 to $7 \mathrm{~m}, 0.5 \mathrm{~m}$ from 7 to $10 \mathrm{~m}$, around $1 \mathrm{~m}$ from 10 to $20 \mathrm{~m}$, and then increasing up to $120 \mathrm{~m}$ at $1200 \mathrm{~m}$ height. MAR data above a height of $1200 \mathrm{~m}$ were not used here since during the investigated period the top of the PBL remained below this value. The MAR model uses primitive equations with the hydrostatic assumption. A description of the model that has been validated with respect to observations from the Automatic Weather Station at Concordia is given by Gallée and Gorodetskaya (2008) and references therein. Parametrization of turbulence in the lowest model layer of MAR is based on the Monin-Obukhov similarity theory (MOST). Above the surface boundary layer, turbulence is parametrized using the E- $\varepsilon$ model, which includes two prognostic equations for turbulent kinetic energy and its dissipation. MAR simulations have been recently validated with respect to observations from the Automatic Weather Station at Concordia for winter (Gallée and Gorodetskaya, 2008) and summer (Gallée et al., 2014). The PBL height was computed from MAR simulations by taking the height where the turbulent kinetic energy decreases below $5 \%$ of the value of the lowest layer of the model.

In Fig. 6 we report the simulated diurnal cycle of the HONO mixing ratio at $1 \mathrm{~m}$ above the ground at Concordia when a photochemical snow release of HONO is applied. The HONO flux used in these calculations was obtained by multiplying the values of the $\mathrm{NO}_{\mathrm{x}}$ snow emission flux derived from field observations at Concordia (Frey et al., 2014) by the temperature-dependent factor reported for surface snow in Table 1. Since, as discussed in Sect. 4, lab experiments indicate no significant change of the ratio of HONO / NOx release when replacing the filter with a $295 \mathrm{~nm}$ cut-off point by the one at $320 \mathrm{~nm}$ (Table 1), and given a maximum of the aqueous absorption cross section for nitrate centred at $300 \mathrm{~nm}$ (Gaffney et al., 1992), we have assumed that the ratio is similar under the two wavelength conditions and used the temperature dependency found when the filter with a cut-off point at $295 \mathrm{~nm}$ was inserted (Table 1). In this way under temperature conditions encountered at $\mathrm{DC}$ we have assumed a $\mathrm{HONO} / \mathrm{NO}_{\mathrm{x}}$ ratio ranging from 0.57 during the day $\left(\right.$ at $-25^{\circ} \mathrm{C}$ ) to 0.3 at night $\left(\right.$ at $-35^{\circ} \mathrm{C}$ ). The derived HONO snow emission flux estimate would represent an upper limit since, as seen in Sect. 4, the upper $12 \mathrm{~cm}$ of snow emits less $\mathrm{HONO}$ than $\mathrm{NO}_{\mathrm{x}}$ compared to 
the surface snow. As seen in Fig. 6, using this upper estimate of the HONO snow emission (mean diurnal value of $0.8 \times 10^{9}$ molecules $\mathrm{cm}^{-2} \mathrm{~s}^{-1}$ ) simulations show that, in addition to around $1.2 \mathrm{pptv}$ of $\mathrm{HONO}$ produced by the NO oxidation, the HONO snow emissions can account for 10.5 pptv of HONO in the atmosphere at Concordia. Assuming a lower HONO-to- $\mathrm{NO}_{\mathrm{x}}$ ratio of snow emissions as suggested by the experiment conducted with the upper $12 \mathrm{~cm}$ of snow collected at DC (Table 1), mean diurnal HONO emission of $0.5 \times 10^{9}$ molecules $\mathrm{cm}^{-2} \mathrm{~s}^{-1}$ is estimated, leading to a related HONO mixing ratio of $6.5 \mathrm{pptv}$ (total of $8 \mathrm{pptv}$ together with NO oxidation). It has to be emphasized that these estimated HONO snow emission fluxes were derived from values of the $\mathrm{HONO} / \mathrm{NO}_{\mathrm{x}}$ photochemical production ratio observed in laboratory experiments carried out by flowing zero air through the snow instead of natural interstitial air of which the chemical composition may be very different.

An upper value of $\mathrm{HONO}-$ to- $\mathrm{NO}_{\mathrm{x}}$ mixing ratios often serves as a reference value to discuss the consistency of HONO mixing ratios (Kleffmann and Wiesen, 2008; Villena et al., 2011). Steady-state calculations indicate that the $\mathrm{HONO} / \mathrm{NO}_{\mathrm{x}}$ ratio reaches a maximum value equal to the ratio of HONO to $\mathrm{NO}_{\mathrm{x}}$ lifetimes $\left(\tau_{\mathrm{HONO}} / \tau_{\mathrm{NO}_{\mathrm{x}}}\right)$, when it is assumed that HONO is the sole source of $\mathrm{NO}_{\mathrm{x}}$. The measured HONO photolysis rate constants (see Sect. 2.2) indicate an atmospheric lifetime of $\mathrm{HONO}$ at DC ranging from 4.5 to $24 \mathrm{~min}$ at 12:00 and 00:00, respectively. Using $\mathrm{OH}$ and $\mathrm{HO}_{2}$ concentrations observed by Kukui et al. (2014), an atmospheric lifetime of $\mathrm{NO}_{\mathrm{x}}$ ranging from $3 \mathrm{~h}$ at 12:00 to $7 \mathrm{~h}$ at 00:00 can be estimated. From that, the upper limit of the $\mathrm{HONO} / \mathrm{NO}_{\mathrm{x}}$ ratio at DC would be close to 0.03 and 0.06 at 12:00 and 00:00, respectively. Using the HONO mixing ratios simulated when a mean diurnal HONO snow emission of $0.8 \times 10^{9}$ molecules $\mathrm{cm}^{-2} \mathrm{~s}^{-1}$ is considered (Fig. 6) and $\mathrm{NO}_{\mathrm{x}}$ mixing ratios observed at Concordia (around $200 \mathrm{pptv}$, Frey et al., 2014), we calculate a mean diurnal $\mathrm{HONO} / \mathrm{NO}_{\mathrm{x}}$ ratio of 0.06 . This value slightly exceeds the maximum steady-state $\mathrm{HONO} / \mathrm{NO}_{\mathrm{x}}$ ratio estimated from $\mathrm{HONO}$ and $\mathrm{NO}_{\mathrm{x}}$ photochemical lifetimes. Note, however, that more accurate estimation of the upper limit of the $\mathrm{HONO} / \mathrm{NO}_{\mathrm{x}}$ ratio should take into account also $\mathrm{HONO}$ and $\mathrm{NO}_{\mathrm{x}}$ vertical distributions determined by the vertical diffusivity and the conversion of $\mathrm{HONO}$ to $\mathrm{NO}_{\mathrm{x}}$, as well as by a possibility of non-steady-state conditions. As the consideration of these factors may lead to a higher $\mathrm{HONO} / \mathrm{NO}_{\mathrm{x}}$ ratio, the higher $\mathrm{HONO} / \mathrm{NO}_{\mathrm{x}}$ ratio of about 0.06 cannot be considered as a strong indication of an error in the simulated HONO mixing ratios derived with an assumed HONO snow emission of $0.8 \times 10^{9}$ molecules $\mathrm{cm}^{-2} \mathrm{~s}^{-1}$.

\section{A possible $\mathrm{HNO}_{4}$ interference on $\mathrm{HONO}$ measurements made with a LOPAP ?}

As discussed in the previous section, field measurements of boundary layer HONO mixing ratios at Concordia in summer (30 pptv) significantly exceed values calculated by considering a HONO snow source estimated from the observed $\mathrm{NO}_{\mathrm{x}}$ snow source and the relative abundance of $\mathrm{HONO}$ and $\mathrm{NO}_{\mathrm{x}}$ releases observed during snow irradiation BAS experiments (8 to 12 pptv). As reported in Sect. 2.4, lab experiments conducted with the LOPAP have shown a possible overestimation of HONO by $\sim 15 \mathrm{pptv}$ due to the presence of $100 \mathrm{pptv}$ of $\mathrm{HNO}_{4}$.

Although $\mathrm{HNO}_{4}$ data are not available at Concordia, its presence is very likely since its atmospheric lifetime with respect to thermal decomposition becomes significant at low temperatures (lifetime close to $2 \mathrm{~h}$ at $-20^{\circ} \mathrm{C}$; Sanders et al., 2011). Whereas the first measurements of $\mathrm{HNO}_{4}$ in Antarctica reported moderate mixing ratios (mean of $25 \mathrm{pptv}$ observed over a few days in December 2000 at the South Pole; Slusher et al., 2002), subsequent investigations have revealed higher values. First, an average of $40 \mathrm{pptv}$ in December to 60 pptv during the second half of November was observed in 2003 at the South Pole (Eisele et al., 2008). Second, a mean value of $64 \mathrm{pptv}$ (up to $150 \mathrm{pptv}$ ) was observed between the ground and $50 \mathrm{~m}$ elevation over the Antarctic Plateau (Slusher et al. 2010). These latter values of the $\mathrm{HNO}_{4}$ mixing ratio together with the above-discussed inconsistencies between simulations and observations stimulate efforts to investigate a possible interference of $\mathrm{HNO}_{4}$ on the LOPAP instrument. Note that, given the $\mathrm{HNO}_{4}$ lifetime with respect to thermal decomposition of a few hours at $-20^{\circ} \mathrm{C}$, we do not expect interference during snow experiments conducted at $\mathrm{BAS}$ since $\mathrm{HNO}_{4}$ initially present in snow collected at DC would have been destroyed during its storage of a few months at $-20^{\circ} \mathrm{C}$. Furthermore, production of $\mathrm{HNO}_{4}$ during the BAS experiments (Sect. 4) following the release of $\mathrm{NO}_{2}$ under irradiation of snow is far too slow to have significantly impacted HONO measurements.

Even though laboratory experiences conducted at PSI under certain conditions clearly showed that there is interference by $\mathrm{HNO}_{4}$ in $\mathrm{HONO}$ measurements made by the LOPAPA instrument (see Sect. 2.4), the absence of $\mathrm{HNO}_{4}$ atmospheric data at Dome $\mathrm{C}$ hampers any accurate attempt to correct $\mathrm{HONO}$ data from the presence of $\mathrm{HNO}_{4}$. Instead, field experiments were conducted at Concordia, heating the air sampled by the LOPAP to thermally decompose $\mathrm{HNO}_{4}$. This air was heated by sucking air through a $8 \mathrm{~m}$ long PFA tube covered with a temperature-controlled heating tape and placed in an insulated box. When heating the tube, the air temperature in the PFA tube was $37^{\circ} \mathrm{C}$, leading to a lifetime of $\mathrm{HNO}_{4}$ with respect to its thermal decomposition of $3.2 \mathrm{~s}$ (Sanders et al., 2011). The experiment was performed by running the LOPAP for $\sim 20 \mathrm{~min}$ with and without heating the tube connected to the inlet of the LOPAP. In order to account 
for possible fast natural change of HONO mixing ratios, the test was repeated three times successively. A systematic drop of HONO values was observed. Given the applied air sampling flow rate of $1.78 \mathrm{~L} \mathrm{~min}^{-1}\left(1 \mathrm{LSTP} \mathrm{min}{ }^{-1}\right)$, the residence time of the air in the tube is $3.3 \mathrm{~s}$. If attributed to the thermal decomposition of $\mathrm{HNO}_{4}$ during the heating (64\% under these working conditions), the mean observed drop of 5.5 pptv of $\mathrm{HONO}$ would correspond to an $\mathrm{HNO}_{4}$ artefact of around 9 pptv.

This indirect estimation of an overestimation of HONO measurements due to the presence of $\mathrm{HNO}_{4}$ is consistent with experiments conducted at PSI if the presence of 50100 pptv of $\mathrm{HNO}_{4}$ is assumed at Concordia. On the other hand, the difference between observed and simulated HONO mixing ratios presented in Sect. 5 suggests a mean diurnal overestimation close to $20 \mathrm{pptv}$ (ranging from $17 \mathrm{pptv}$ around noon to 22 pptv during the night). In their discussions of the observed levels of $\mathrm{HO}_{\mathrm{x}}$ radicals, Kukui et al. (2014) found that the consideration of $30 \mathrm{pptv}$ of HONO is inconsistent with radical observations leading to about 2 times overestimation of $\mathrm{RO}_{2}$ and $\mathrm{OH}$ concentrations. Conversely, neglecting the $\mathrm{OH}$ production from HONO leads to an underestimation of radical levels by a factor of 2. Kukui et al. (2014) showed that a quite fair agreement with $\mathrm{OH}$ measurements is achieved with HONO mixing ratios derived from the 1-D modelling, with a HONO snow emission flux equal to about $30 \%$ of that of $\mathrm{NO}_{\mathrm{x}}$. Finally, though being slightly higher, the best guess of HONO mixing ratios derived in Sect. 5 for DC ( 8 to 12 pptv) are in the range of mixing ratios measurements made at the South Pole using laser-induced fluorescence (6 pptv; Liao et al., 2006).

\section{Conclusions}

This second study of HONO conducted in the atmosphere of the East Antarctic Plateau by deploying a LOPAP confirms unexpectedly high mixing ratios close to $30 \mathrm{pptv}$. A mixing ratio of $8-12$ pptv can be rationalized based on emissions of HONO from snow of $0.5-0.8 \times 10^{9}$ molecules $\mathrm{cm}^{-2} \mathrm{~s}^{-1}$ derived from studies of the irradiation experiments surface snow collected at DC and scaled down to the $\mathrm{NO}_{\mathrm{x}}$ emissions derived from observations made at Concordia by Frey et al. (2014). Experiments conducted in the field and in the lab to identify the cause of such a discrepancy point to a possible overestimation of $\mathrm{HONO}$ in the range of 10 to $20 \mathrm{pptv}$ due to the important presence of $\mathrm{HNO}_{4}$ in this cold atmosphere. An accurate correction of the HONO data from the presence of $\mathrm{HNO}_{4}$ is not yet possible. Further work - both in the lab, to quantify the interference at different levels of $\mathrm{HNO}_{4}$, and in the presence of various other species and in the field at Concordia, to obtain mixing ratios of HONO and $\mathrm{HNO}_{4}$ at the same time - is needed.
Acknowledgements. The OPALE project was funded by the ANR (Agence National de Recherche) contract ANR-09-BLAN-0226. The measurement of the specific snow area was developed in the framework of the MONISNOW projet funded by the ANR-11JS56-005-01 contract. National financial support and field logistic supplies for the summer campaign were provided by Institut Polaire Français-Paul Emile Victor (IPEV) within programmes No. 414, 903, and 1011. M. D. King was supported by NERC NE/F0004796/1 and NE/F010788, and NERC FSF grants 555.0608 and 584.0609. Thanks to our Italian colleagues from MeteoClimatological Observatory of PNRA for the meteorological data collected at Concordia.

Edited by: J. W. Bottenheim

\section{References}

Arnaud, L., Picard, G., Champollion, N., Dominé, F., Gallet, J. C., Lefebvre, E., Fily, M., and Barnola, J. M.: Measurement of vertical profiles of snow specific surface area with a $1 \mathrm{~cm}$ resolution using infrared reflectance: instrument description and validation, J. Glaciol., 57, 17-29, 2011.

Bartels-Rausch, T., Brigante, M., Elshorbany, Y. F., Ammann, M., D’Anna, B., George, C., Stemmler, K., Ndour, M., and Kleffmann, J.: Humic acid in ice: Photo-enhanced conversion of nitrogen dioxide into nitrous acid, Atmos. Environ., 44, 5443-5450, doi:10.1016/j.atmosenv.2009.12.025, 2010.

Bartels-Rausch, T., Ulrich, T., Huthwelker, T., and Ammann, M.: A novel synthesis of the radiactively labelled atmospheric trace gas peroxynitric acid, Radiochim. Acta, 99, 1-8, doi:10.1524/ract.2011.1830, 2011.

Bauguitte, S. J.-B., Bloss, W. J., Evans, M. J., Salmon, R. A., Anderson, P. S., Jones, A. E., Lee, J. D., Saiz-Lopez, A., Roscoe, H. K., Wolff, E. W., and Plane, J. M. C.: Summertime NOx measurements during the CHABLIS campaign: can source and sink estimates unravel observed diurnal cycles?, Atmos. Chem. Phys., 12, 989-1002, doi:10.5194/acp-12-989-2012, 2012.

Beine, H. J., Amoroso, A., Dominé, F., King, M. D., Nardino, M., Ianniello, A., and France, J. L.: Surprisingly small HONO emissions from snow surfaces at Browning Pass, Antarctica, Atmos. Chem. Phys., 6, 2569-2580, doi:10.5194/acp-6-2569-2006, 2006.

Calace, N., Cantafora, E., Mirante, S., Petronio, B. M., and Pietroletti, M.: Transport and modification of humic substances present in Antarctic snow and ancient ice, J. Environ. Monit., 7, 1320$1325,2005$.

Chan, W. H., Nordstrom, R. J., Galvert, J. G., and Shaw, J. H.: An IRFTS spectroscopic study of the kinetics and the mechanism of the reactions in the gaseous system, HONO, NO, $\mathrm{NO}_{2}, \mathrm{H}_{2} \mathrm{O}$, Chem. Phys. Lett., 37, 441-446, doi:10.1016/00092614(76)85010-5, 1976.

Chen, G., Davis, D., Crawford, J., Nowak, J. B., Eisele, F., Mauldin III, R. L., Tanner, D., Buhr, M., Shetter, R., Lefer, B., Arimoto, R., Hogan, A., and Blake, D.: An investigation of South Pole $\mathrm{HO}_{\mathrm{x}}$ chemistry: comparison of model results with ISCAT observations, Geophys. Res. Lett., 28, 3633-3636, 2001.

Chen, G., Davis, D., Crawford, J., Mauldin III, R. L., Eisele, F., Huey, G., Slusher, D., Tanner, D., Dibb, J., Buhr, M., Hutterli, M., McConnell, J., Lefer, B., Shetter, R., Blake, D., Lombardi, 
K., and Arnoldy, J.: A reassessment of $\mathrm{HO}_{x}$ South Pole chemistry based on observations recorded during ISCAT 2000, Atmos. Environ., 38, 5451-5461, doi:10.1016/j.atmosenv.2003.07.018, 2004.

Cotter, E. S. N., Jones, A. E., Wolff, E. W., and Bauguitte, S. J.B.: What controls photochemical $\mathrm{NO}$ and $\mathrm{NO}_{2}$ production from Antarctic snow? Laboratory investigation assessing the wavelength and temperature dependence, J. Geophys. Res., 108, 4147, doi:10.1029/2002JD002602, 2003.

Crowley, J. N., Ammann, M., Cox, R. A., Hynes, R. G., Jenkin, M. E., Mellouki, A., Rossi, M. J., Troe, J., and Wallington, T. J.: Evaluated kinetic and photochemical data for atmospheric chemistry: Volume V - heterogeneous reactions on solid substrates, Atmos. Chem. Phys., 10, 9059-9223, doi:10.5194/acp-10-90592010, 2010.

Davis, D., Nowak, J. B., Chen, G., Buhr, M., Arimoto, R., Hogan, A., Eisele, F., Mauldin, L., Tanner, D., Shetter, R., Lefer, B., and McMurry, P.: Unexpected high levels of NO observed at South Pole, Geophys. Res. Lett., 28, 3625-3628, doi:10.1029/2000GL012584, 2001.

Dibb, J. E., Arsenault, M., Peterson, M. C., and Honrath, R. E.: Fast nitrogen oxide photochemistry in Summit, Greenland snow, Atmos. Environ., 36, 2501-2511, doi:10.1016/S13522310(02)00130-9, 2002

Dibb, J. E., Huey, L. G., Slusher, D. L., and Tanner, D. J.: Soluble reactive nitrogen oxides at South Pole during ISCAT 2000, Atmos. Environ., 38, 5399-5409, 2004.

Eisele, F., Davis, D. D., Helmig, D., Oltmans, S. J., Neff, W., Huey, G., Tanner, Chen, G., Crawford, J., Arimoto, R., Buhr, M., J., Mauldin, L., Hutterli, M., Dibb, J., Blake, D., Brooks, S. B., Johnson, B., Roberts, J. M., Wang, Y., Tan, D., and Flocke, F.: Antarctic tropospheric chemistry investigation (ANTCI) 2003 overview, Atmos. Environ., 42, 2749-2761, doi:10.1016/j.atmosenv.2007.04.013, 2008.

Finlayson-Pitts, B. J., Wingen, L. M., Sumner, A. L., Syomin, D., and Ramazan, K. A.: The heterogeneous hydrolysis of $\mathrm{NO}_{2}$ in laboratory systems and in outdoor and indoor atmospheres: An integrated mechanism, Phys. Chem. Chem. Phys., 5, 223-242, doi:10.1039/b208564j, 2003.

France, J. L., King, M. D., Frey, M. M., Erbland, J., Picard, G., Preunkert, S., MacArthur, A., and Savarino, J.: Snow optical properties at Dome C (Concordia), Antarctica; implications for snow emissions and snow chemistry of reactive nitrogen, Atmos. Chem. Phys., 11, 9787-9801, doi:10.5194/acp-11-97872011, 2011.

Frey, M. M., Brough, N., France, J. L., Anderson, P. S., Traulle, O., King, M. D., Jones, A. E., Wolff, E. W., and Savarino, J.: The diurnal variability of atmospheric nitrogen oxides (NO and $\mathrm{NO}_{2}$ ) above the Antarctic Plateau driven by atmospheric stability and snow emissions, Atmos. Chem. Phys., 13, 3045-3062, doi:10.5194/acp-13-3045-2013, 2013.

Frey, M. M., Roscoe, H. K., Kukui, S., Savarino, J., France, J. L., King, M. D., Legrand, M., and Preunkert, S.: Atmospheric nitrogen oxides ( $\mathrm{NO}$ and $\mathrm{NO}_{2}$ ) at Dome $\mathrm{C}$, East Antarctica, during the OPALE campaign, submitted, 2014.

Gaffney, J. S., Marley, N. A., and Cunningham, M. M.: Measurement of the absorption constants for nitrate in water between 270 and 335 nm, Environ. Sci. Technol., 25, 207-209, 1992.
Gallet, J.-C., Domine, F., Arnaud, L., Picard, G., and Savarino, J.: Vertical profile of the specific surface area and density of the snow at Dome C and on a transect to Dumont D'Urville, Antarctica - albedo calculations and comparison to remote sensing products, The Cryosphere, 5, 631-649, doi:10.5194/tc-5-6312011, 2011.

Gallée, H. and Gorodetskaya, I.: Validation of a limited area model over Dome C, Antarctic Plateau, during winter, Clim. Dynam., 34, 61-72, doi:10.1007/s00382-008-0499-y, 2008.

Gallée, H., Preunkert, S., Argentini, S., Frey, M., Genthon, C., Jourdain, B., Pietroni, I., Casasanta, G., Barral, H., Vignon E., and Legrand, M.: Characterization of the boundary layer at Dome C during OPALE, Atmos. Chem. Phys. Discuss., in preparation, 2014.

George, C., Strekowski, R. S., Kleffmann, J., Stemmler, K., and Ammann, M.: Photoenhanced uptake of gaseous $\mathrm{NO}_{2}$ on solid organic compounds: a photochemical source of HONO, Faraday Discuss., 130, 195-211, 2005.

Grannas, A. M., Jones, A. E., Dibb, J., Ammann, M., Anastasio, C., Beine, H. J., Bergin, M., Bottenheim, J., Boxe, C. S., Carver, G., Chen, G., Crawford, J. H., Dominé, F., Frey, M. M., Guzmán, M. I., Heard, D. E., Helmig, D., Hoffmann, M. R., Honrath, R. E., Huey, L. G., Hutterli, M., Jacobi, H. W., Klán, P., Lefer, B., McConnell, J., Plane, J., Sander, R., Savarino, J., Shepson, P. B., Simpson, W. R., Sodeau, J. R., von Glasow, R., Weller, R., Wolff, E. W., and Zhu, T.: An overview of snow photochemistry: evidence, mechanisms and impacts, Atmos. Chem. Phys., 7, 43294373, doi:10.5194/acp-7-4329-2007, 2007.

Gutzwiller, L., Arens, F., Baltensperger, U., Gäggeler, H. W., and Ammann, M.: Significance of semivolatile diesel exhaust organics for secondary HONO formation, Environ. Sci. Technol., 36, 677-682, doi:10.1021/es015673b, 2002.

Heland, J., Kleffmann, J., Kurtenbach, R., and Wiesen, P.: A new instrument to measure gaseous nitrous acid (HONO) in the atmosphere, Environ. Sci. Technol., 35, 3207-3212, doi:10.1021/es000303t, 2001.

Hudson, S. R., Warren, S. G., Brandt, R. E., Grenfell, T. C., and Six, D.: Spectral bidirectional reflectance of Antarctic snow: Measurements and parameterization, J. Geophys. Res., 111, D18106, doi:10.1029/2006JD007290, 2006.

Jones, A. E., Weller, R., Wolff, E. W., and Jacobi, H.-W.: Speciation and rate of photochemical $\mathrm{NO}$ and $\mathrm{NO}_{2}$ production in Antarctic snow, Geophys. Res. Lett., 27, 345-348, 2000.

Kerbrat, M., Legrand, M., Preunkert, S., Gallée, H., and Kleffmann, J.: Nitrous Acid at Concordia on the East Antarctic Plateau and its transport to the coastal site of Dumont d'Urville, J. Geophys. Res., 117, D08303, doi:10.1029/2011JD017149, 2012.

Kirchstetter, T. W., Harley, R. A., and Littlejohn, D.: Measurement of nitrous acid in motor vehicle exhaust, Environ. Sci. Technol., 30, 2843-2849, doi:10.1021/es960135y, 1996.

Kleffmann, J., Heland, J., Kurtenbach, R., Lorzer, J., and Wiesen, P.: A new instrument (LOPAP) for the detection of nitrous acid (HONO), Environ. Sci. Pollut. Res. (Sp. Iss. 4), 48-54, 2002.

Kleffmann, J. and Wiesen, P.: Technical Note: Quantification of interferences of wet chemical HONO LOPAP measurements under simulated polar conditions, Atmos. Chem. Phys., 8, 6813-6822, doi:10.5194/acp-8-6813-2008, 2008.

Kokhanovsky, A. A., and Zege, E. P.: Scattering optics of snow, Appl. Optics, 43, 1589-1602, 2004. 
Kukui, A., Legrand, M., Ancellet, G., Gros, V., Bekki, S., SardaEstève, R., Loisil, R., and Preunkert, S.: Measurements of $\mathrm{OH}$ and $\mathrm{RO}_{2}$ radicals at the coastal Antarctic site of Dumont d'Urville (East Antarctica) in summer, J. Geophys. Res., 117, D12310, doi:10.1029/2012JD017614, 2012.

Kukui, A., Legrand, M., Preunkert, S., Frey, M. M., Loisil, R., Gil Roca, J., Jourdain, B., King, M. D., France, J. L., and Ancellet, G.: Measurements of $\mathrm{OH}$ and $\mathrm{RO}_{2}$ radicals at Dome C, East Antarctica, Atmos. Chem. Phys. Discuss., 14, 14999-15044, doi:10.5194/acpd-14-14999-2014, 2014.

Kurtenbach, R., Becker, K. H., Gomes, J. A. G., Kleffmann, J., Lorzer, J. C., Spittler, M., Wiesen, P., Ackermann, R., Geyer, A., and Platt, U.: Investigations of emissions and heterogeneous formation of HONO in a road traffic tunnel, Atmos. Environ., 35, 3385-3394, 10.1016/s1352-2310(01)00138-8, 2001.

Legrand M., Preunkert, S., Jourdain, B., Gallée, H., Goutail, F., Weller R., and Savarino, J.: Year round record of surface ozone at coastal (Dumont d'Urville) and inland (Concordia) sites in East Antarctica, J. Geophys. Res., 114, D20306, doi:10.1029/2008JD011667, 2009.

Legrand, M., Preunkert, S., Jourdain, B., Guilhermet, J., Faïn, X., Alekhina, I., and Petit, J. R.: Water-soluble organic carbon in snow and ice deposited at Alpine, Greenland, and Antarctic sites: a critical review of available data and their atmospheric relevance, Clim. Past, 9, 2195-2211, doi:10.5194/cp-9-2195-2013, 2013.

Li, X., Rohrer, F., Hofzumahaus, A., Brauers, T., Häseler, R., Bohn, B., Broch, S., Fuchs, H., Gomm, S., Holland, F., Jäger, J., Kaiser, J., Keutsch, F. N., Lohse, I., Lu, K., Tillmann, R., Wegener, R., Wolfe, G. M., Mentel, T. F., Kiendler-Scharr, A., and Wahner, A.: Missing Gas-Phase Source of HONO Inferred from Zeppelin Measurements in the Troposphere, Science, 344, 292-296, 2014.

Liao, W., Case, A. T., Mastromarino, J., Tan, D., and Dibb, J. E.: Observations of HONO by laser-induced fluorescence at the South Pole during ANTCI 2003, Geophys. Res. Lett., 33, L09810, doi:10.1029/2005GL025470, 2006.

Mauldin III, R. L., Eisele, F. L., Tanner, D. J., Kosciuch, E., Shetter, R., Lefer, B., Hall, S. R., Nowak, J. B., Buhr, M., Chen, G., Wang, P., and Davis, D.: Measurements of $\mathrm{OH}, \mathrm{H}_{2} \mathrm{SO}_{4}$, and MSA at the South Pole during ISCAT, Atmos. Environ., 28, 3629-3632, 2001a.

Mauldin III, R. L., Eisele, F. L., Cantrell, C. A., Koscisuch, E., Ridley, B. A., Lefer, B., Tanner, D. J., Nowak, J. B., Chen, G., Wang, L., and Davis, D.: Measurements of OH aboard the ASA P-3 during PEM-Tropics B., J. Geophys. Res., 106, 32 657-32 666, 2001 b.
Meusinger, C., Berhanu, T. A., Erbland, J., Savarino, J., and Johnson, M. S.: Laboratory Study of Nitrate Photolysis in Antarctic Snow, Part 1: Observed Quantum Yield, Domain of Photolysis and Secondary Chemistry, J. Chem. Phys., 244305, doi:10.1063/1.4882898, 2014.

Preunkert, S., Ancellet, G., Legrand, M., Kukui, A., Kerbrat, M., Sarda-Estève, R., Gros, V., and Jourdain, B.: Oxidant Production over Antarctic Land and its Export (OPALE) project: An overview of the 2010-2011 summer campaign, J. Geophys. Res., 117, D15307, doi:10.1029/2011JD017145, 2012.

Regimbal, J. and Mozurkewich, M.: Peroxynitric acid decay mechanisms and kinetics at low pH, J. Phys. Chem. A, 101, 8822-8829, 1997.

Sander, S. P. and Peterson, A. E.: Kinetics of the reaction $\mathrm{HO}_{2}+\mathrm{NO}_{2}+\mathrm{M} \rightarrow \mathrm{HO}_{2} \mathrm{NO}_{2}+\mathrm{M}$, J. Phys. Chem., 88, 166-1571, 1984.

Sander, S. P., Abbatt, J., Barker, J. R., Burkholder, J. B., Friedl, R. R., Golden, D. M., Huie, R. E., Kolb, C. E., Kurylo, M. J., Moortgat, G. K., Orkin, V. L., and Wine, P. H.: Chemical Kinetics and Photochemical Data for Use in Atmospheric Studies, Evaluation No. 17, JPL Publication 10 June 2011, Jet Propulsion Laboratory, Pasadena, http://jpldataeval.jpl.nasa.gov, 2011.

Slusher, D. L., Huey, L. G., Tanner, D. J., Chen, G., Davis, D. D., Buhr, M., Nowak, J. B., Eisele, F., Kosciuch, E., Mauldin III, R. L., Lefer, B. L., Shetter, R. E., and Dibb, J. E.: Measurements of pernitric acid at the South Pole during ISCAT 2000, Geophys. Res. Lett., 29, 2011, doi:10.1029/2002GL015703, 2002.

Slusher, D. L., Neff, W. D., Kim, S., Huey, L. G., Wang, Y., Zeng, T., Tanner, D. J., Blake, D. R., Beyersdorf, A., Lefer, B. L., Crawford, J. H., Eisele, F. L., Mauldin III, R. L., Kosciuch, E., Buhr, M. P., Wallace, H. W., and Davis, D. D.: Atmospheric chemistry results from the ANTCI 2005 Antarctic plateau airborne study, J. Geophys. Res.-Atmos., 115, D07304, doi:10.1029/2009JD012605, 2010.

Ulrich, T., Ammann, M., Leutwyler, S., and Bartels-Rausch, T.: The adsorption of peroxynitric acid on ice between $230 \mathrm{~K}$ and $253 \mathrm{~K}$, Atmos. Chem. Phys., 12, 1833-1845, doi:10.5194/acp-12-18332012, 2012.

Villena, G., Wiesen, P., Cantrell, C. A., Flocke, F., Fried, A., Hall, S. R., Hornbrook, R. S., Knapp, D., Kosciuch, E., Mauldin III, R. L., McGrath, J. A., Montzka, D., Richter, D., Ullmann, K., Walega, J., Weibring, P., Weinheimer, A., Staebler, R. M., Liao, J., Huey, L. G., and Kleffmann, J.: Nitrous acid (HONO) during polar spring in Barrow, Alaska: A net source of OH radicals?, J. Geophys. Res., 116, D00R07, doi:10.1029/2011JD016643, 2011. 